\title{
Presentation
}

\section{Analyses of Entry Mechanisms of Novel Emerging Viruses Using Pseudotype VSV System}

\author{
Hideki Tani \\ Published online 27 May, 2014
}

\begin{abstract}
Emerging infectious diseases include newly identified diseases caused by previously unknown organisms or diseases found in new and expanding geographic areas. Viruses capable of causing clinical disease associated with fever and bleeding are referred to as viral hemorrhagic fevers (VHFs). Arenaviruses and Bunyaviruses, both belonging to families classified as VHFs are considered major etiologies of hemorrhagic fevers caused by emerging viruses; having significant clinical and public health impact. Because these viruses are categorized as Biosafety Level (BSL) 3 and 4 pathogens, restricting their use, biological studies including therapeutic drug and vaccine development have been impeded. Due to these restrictions and the difficulties in handling such live viruses, pseudotype viruses bearing envelope proteins of VHF viruses have been developed using vesicular stomatitis virus (VSV) as a surrogate system. Here, we report the successful developments of two pseudotype VSV systems; bearing the envelope proteins of Lujo virus and severe fever with thrombocytopenia syndrome (SFTS) virus, both recently identified viruses of the family Arenaviridae and Bunyaviridae, respectively. My presentation will summarize the characterization of the envelope proteins of Lujo virus including its cellular receptor use and cell entry mechanisms. In addition, I will also present a brief introduction of SFTS reported in Japan and the diagnostic studies in progress using these newly pseudotype VSV system.
\end{abstract}

Key words: Arenavirus, Bunyavirus, pseudotype, Cell fusion, entry, SFTSV, Lujo virus

Thank you, Dr. Morikawa. First of all, thank you very much for giving me this opportunity to present our recent data in this meeting. Today, I'd like to talk about the entry mechanisms of two novel emerging viruses using pseudotype VSV system.

Today's presentation:

1. Characterization of Lujo virus GP and cell entry

2. Severe fever with thrombocytopenia syndrome (SFTS) in Japan

Today's my presentation is two topics. The first part is the characterization of novel Arenavirus, Lujo virus, GP and its cell entry. The second part is the recent sensational infectious disease, severe fever with thrombocytopenia syndrome, SFTS, in Japan (Fig. 1).

Okay, let's start the first part. The Arenaviral hemorrhagic fevers are caused by various Arenaviruses, which are distributed in South American and African continents as shown here $[1,2]$. In this study, we focused on four significant arenaviruses shown in red letter, especially the Lujo virus which is recently isolated in Southern Africa [3] (Fig. 2).

Arenaviruses are categorized as New World arenavi- ruses and Old World arenaviruses [2]. Some of the arenaviruses defined host in nature, disease, case fatality, and entry receptors. However, the Lujo virus is still largely unknown [3, 4] (Fig. 3).

The Lujo virus is a novel arenavirus discovered in 2008 at Lusaka and Johannesburg. The first letter of the place name joined and designated Lujo. The Lujo virus shows high case fatality rate and is classified as a BSL-4 pathogen. Lujo virus is a highly novel genetic lineage apart from the Lassa virus or Junin virus. The Lujo virus is unknown for the entry mechanisms including receptors. So, the aim of this study is to clarify the characteristics of Lujo virus GP and to examine the entry mechanisms of Lujo virus by using pseudotype VSV (Fig. 4).

This is the schematic representation of the construction of the pseudotype VSVs [5]. The parental VSV encoding the luciferase gene instead of the VSV-G infect to the producing cells expressing arenavirus GPs. The viruses budded from these cells are arenavirus-GP pseudotype VSV.

The characteristics of the pseudotype virus is a useful tool examination of viral entry because of single infection,

Department of Virology I, National Institute of Infectious Diseases, 4-7-1 Gakuen, Musashimurayama Tokyo 208-0011, Japan 


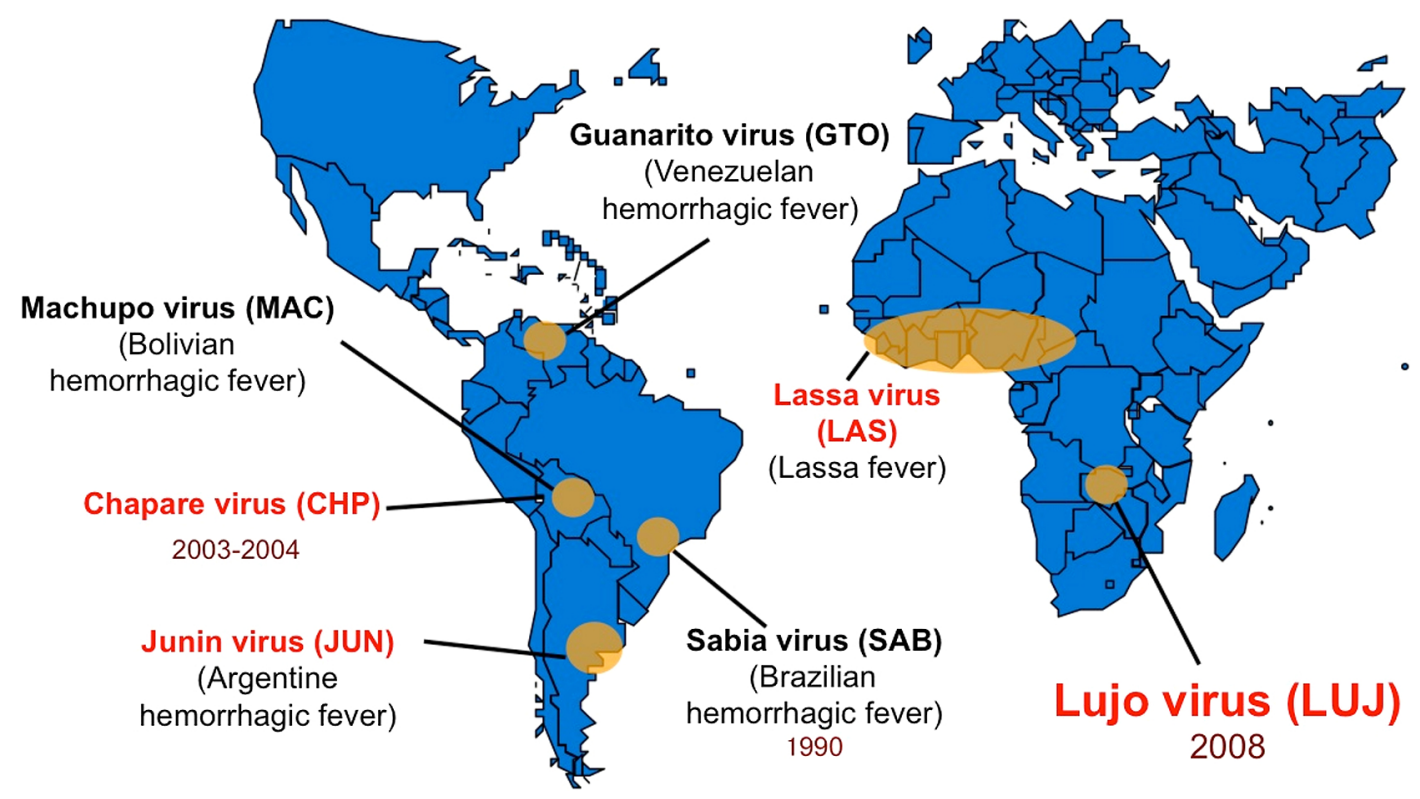

Fig. 1. Geographic distribution of arenaviral hemorrhagic fevers

\begin{tabular}{|c|c|c|c|c|}
\hline Virus & Host in Nature & Disease & $\begin{array}{c}\text { Case } \\
\text { Fatality }\end{array}$ & Receptor \\
\hline \multicolumn{5}{|c|}{ New World arenavirus (NWA) } \\
\hline Junin (JUNV) & Calomys musculinus & $\begin{array}{l}\text { Argentine hemorrhagic } \\
\text { fever (AHF) }\end{array}$ & $15-30 \%$ & TfR1 \\
\hline Machupo (MACV) & Calomys callosus & $\begin{array}{l}\text { Bolivian hemorrhagic } \\
\text { fever }\end{array}$ & $25 \%$ & TfR1 \\
\hline Guanarito (GTOV) & $\begin{array}{l}\text { Zygodontomys } \\
\text { brevicauda }\end{array}$ & $\begin{array}{l}\text { Venezuelan hemorrhagic } \\
\text { fever }\end{array}$ & $25 \%$ & TfR1 \\
\hline Sabia (SABV) & Unknown & $\begin{array}{l}\text { Brazilian hemorrhagic } \\
\text { fever }\end{array}$ & $1 / 3$ & TfR1 \\
\hline Chapare (CHPV) & Unknown & Not yet named & 1 tatal case & TfR1 \\
\hline \multicolumn{5}{|l|}{ Old World arenavirus (OWA) } \\
\hline Lassa (LASV) & Mastomys species & Lassa fever & $10-15 \%$ & $a D G$ \\
\hline $\begin{array}{l}\text { Lymphocytic choriomeningitis virus } \\
\text { (LCMV) }\end{array}$ & $\begin{array}{l}\text { Mus domesticus } \\
\text { Mus musculus }\end{array}$ & $\begin{array}{l}\text { Lymphocytic } \\
\text { choriomeningitis }\end{array}$ & $<1 \%$ & $\mathrm{aDG}$ \\
\hline Lujo (LUJV) & Unknown & Not yet named & $4 / 5$ & ? \\
\hline
\end{tabular}

Fig. 2. Arenaviruses known to be human pathogens

and is safety because of using only envelope gene even if BSL-4 pathogen, and is easy construction just only single transfection of the plasmid and VSV infection, and is easy evaluation of the infectivity because of encoding the reporter gene such as GFP, luciferase, or secreted alkaline phosphatase [5] (Fig. 5).

This slide shows their incorporation and glycosylation of flag-tagged arenavirus GP into the virions. All of the arenavirus GPs were efficiently incorporated into the virions and showed high-mannose type of glycosylation because of being sensitive to the endoglycosidase- $\mathrm{H}$ treatment. In contrast, VSV-G showed complex-type of glycosylation because of resistance to the endoglycosidase- $\mathrm{H}$ treatment (Fig. 6).

Next, we examined the infectivities of arenavirus pseudotype in various mammalian cells. All of the arenavi- rus pseudotypes can infect many types of cells, but Lujo virus pseudotype is not susceptible to the mouse-derived cell lines, NIH3T3 and normal murine liver cells, NMuLi, and human T-cell derived Molt- 4 cells. The Lassa virus pseudotype is also not susceptible to the Jurkat cells as reported previously [6] (Fig. 7).

Next to determine whether the arenavirus pseudotypes show the pH-dependent entry, the bafilomycin, ammonium chloride or chloroquine, which are the inhibitors of endosomal acidification, were utilized [7]. As you can see, all of the arenavirus pseudotype infections were inhibited by these inhibitors in dose-dependent manner. The control virus, murine leukemia virus pseudotype, which causes direct fusion at the plasma membrane, has no influence (Fig. 8).

I'd like to remind you again that New World arenaviruses use the transferrin receptor 1 as a receptor for the entry, and Old World arenaviruses use alpha-dystroglycan $(\alpha-D G)$ as a receptor [2]. So, next we examined whether the Lujo virus uses these receptors (Fig. 9).

At first, we examined the inhibition of arenavirus pseudotype infection by anti-human TfR1 monoclonal antibody. As you can see, the Junin virus and Chapare virus pseudotype infections were inhibited by the antihuman TfR1 antibody. In contrast, the Lujo virus as well as Lassa virus pseudotype infections exhibited no inhibition (Fig. 10).

Furthermore, we confirmed involvement of TfR1 by using the $\mathrm{CHO}$ cells expressing human TfR1. As you can see, the Junin virus and Chapare virus pseudotype infec- 


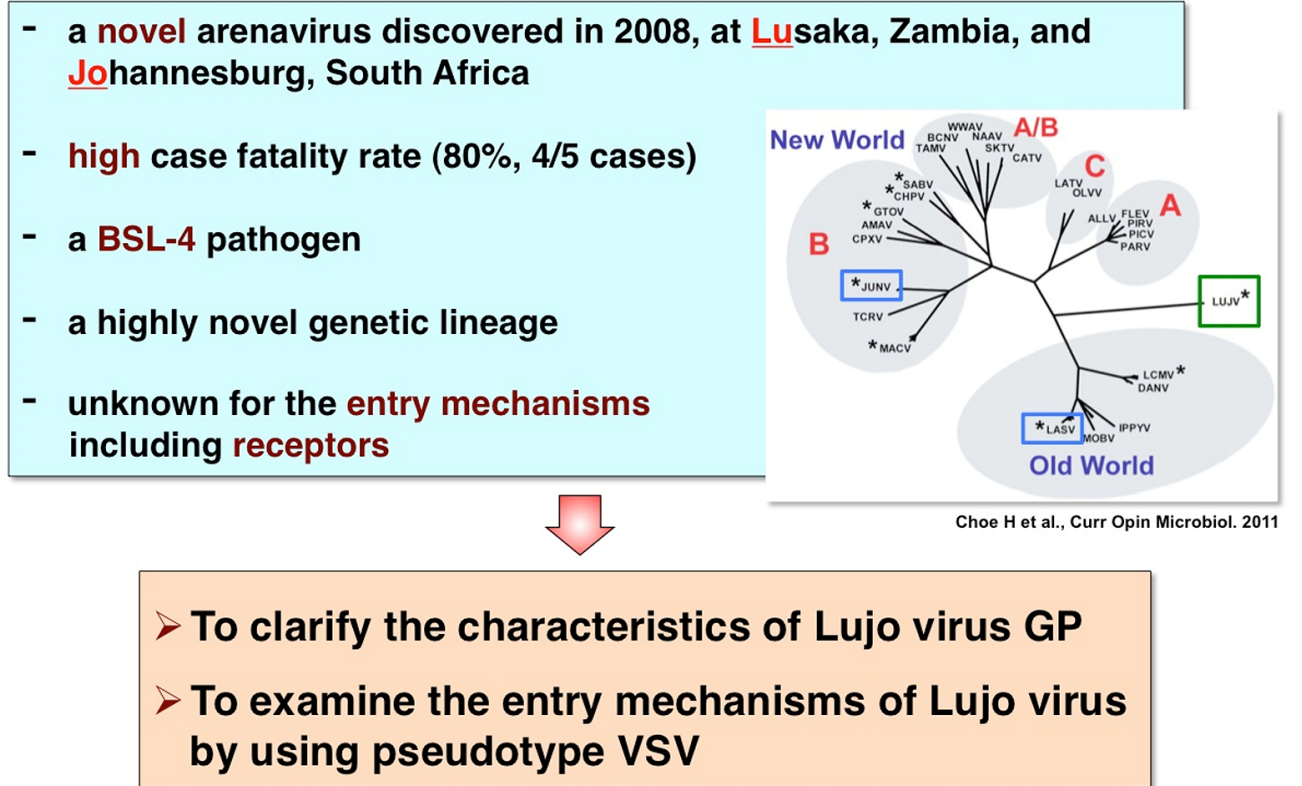

Fig. 3. Lujo virus

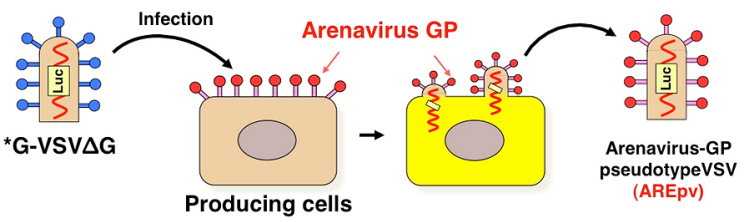

Pseudotype virus (PV)

A useful tool for examination of viral entry because of single infection. Safety because of using only envelope gene, even if BSL-4 pathogens. Easy construction.

Easy evaluation of the infectivity because of reporter gene.

Fig. 4. Construction of the pseudotype VSVs

tions were increased in the $\mathrm{CHO}$ cells expressing human TfR 1 compared with the parenteral CHO cells. In contrast, Lujo virus as well as Lassa virus pseudotype infection was no significant increase in these cells. These results indicate that Lujo virus pseudotype infection is independent of TfR1-mediated entry (Fig. 11).

Next, we examined the involvement of $\alpha$-DG. Many Old World arenaviruses such as Lassa virus can use Omannosylated $\alpha-\mathrm{DG}$ as a receptor for the entry $[2,8]$. So, to determine whether Lujo virus can use it, we utilized the Raji or Jurkat cells expressing LARGE. The LARGE is one of the glycosylation enzymes and causes hyperglycosylation of $\alpha-\mathrm{DG}$.

As you can see, the Lassa virus pseudotype infection is increased in both Raji and Jurkat cells expressing

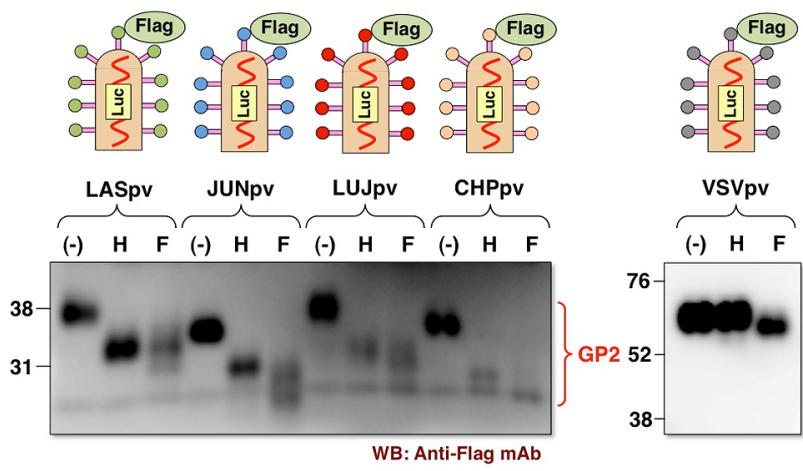

(-): Non treatment, H: Endoglycosidase H, F: PNGase F

Fig. 5. Incorporation and glycosylation of arenavirus GP into virions

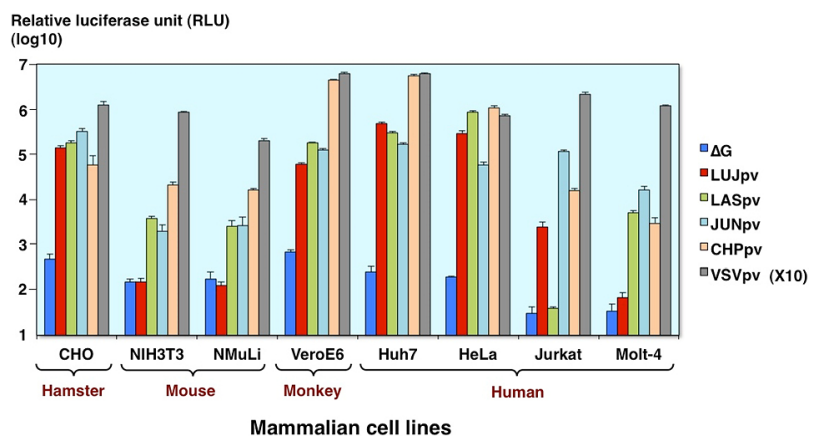

Fig. 6. Infectivities of AREpv in various mammalian cells

LARGE. In contrast, the Lujo virus and other pseudotype virus infection was no significant increase (Fig. 12). 

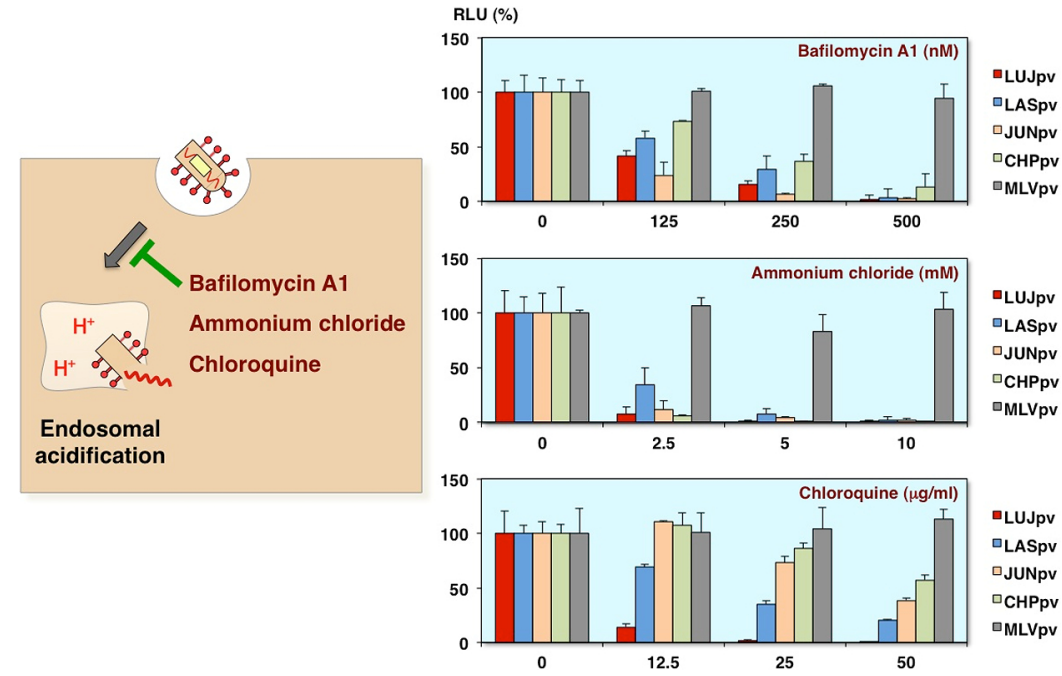

Fig. 7. Inhibition of AREpv infection by $\mathrm{H}^{+}$-ATPase inhibitors

\begin{tabular}{|c|c|c|c|c|}
\hline Virus & Host in Nature & Disease & $\begin{array}{c}\text { Case } \\
\text { Fatality }\end{array}$ & Receptor \\
\hline \multicolumn{5}{|c|}{ New World arenavirus (NWA) } \\
\hline Junin (JUNV) & Calomys musculinus & $\begin{array}{l}\text { Argentine hemorrhagic } \\
\text { fever (AHF) }\end{array}$ & $15-30 \%$ & TfR1 \\
\hline Machupo (MACV) & Calomys callosus & $\begin{array}{l}\text { Bolivian hemorrhagic } \\
\text { fever }\end{array}$ & $25 \%$ & TfR1 \\
\hline Guanarito (GTOV) & $\begin{array}{l}\text { Zygodontomys } \\
\text { brevicauda }\end{array}$ & $\begin{array}{l}\text { Venezuelan hemorrhagic } \\
\text { fever }\end{array}$ & $25 \%$ & TfR1 \\
\hline Sabia (SABV) & Unknown & $\begin{array}{l}\text { Brazilian hemorrhagic } \\
\text { fever }\end{array}$ & $1 / 3$ & TfR1 \\
\hline Chapare (CHPV) & Unknown & Not yet named & 1 tatal case & TfR1 \\
\hline \multicolumn{5}{|l|}{ Old World arenavirus (OWA) } \\
\hline Lassa (LASV) & Mastomys species & Lassa fever & $10-15 \%$ & $a D G$ \\
\hline $\begin{array}{l}\text { Lymphocytic choriomeningitis virus } \\
\text { (LCMV) }\end{array}$ & $\begin{array}{l}\text { Mus domesticus } \\
\text { Mus musculus }\end{array}$ & $\begin{array}{l}\text { Lymphocytic } \\
\text { choriomeningitis }\end{array}$ & $<1 \%$ & $\mathrm{aDG}$ \\
\hline Lujo (LUJV) & Unknown & Not yet named & $4 / 5$ & $?$ \\
\hline
\end{tabular}

Fig. 8. Arenaviruses known to be human pathogens

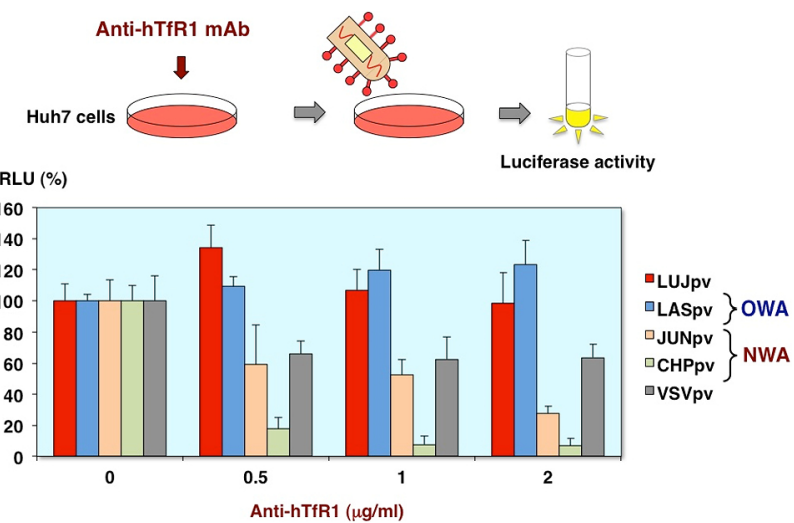

Fig. 9. Inhibition of AREpv infection by anti-human TfR1 antibody

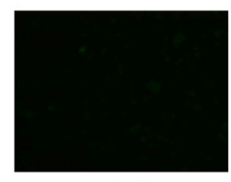

$\mathrm{CHO}$

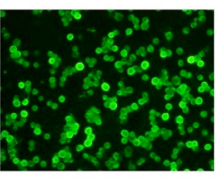

CHO-hTRR1

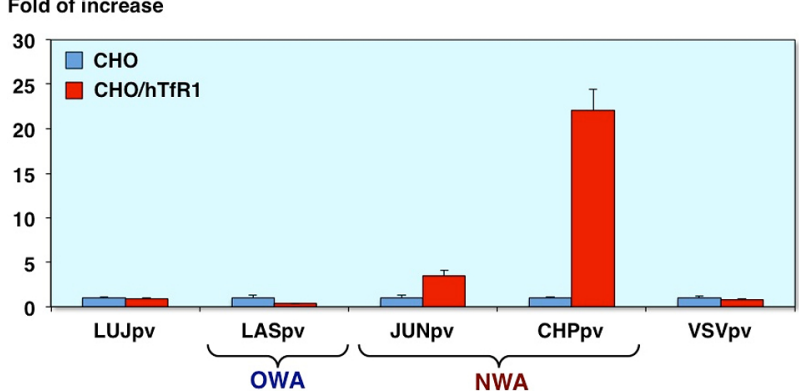

Fig. 10. Infectivities of AREpv in CHO cells expressing hTfR1
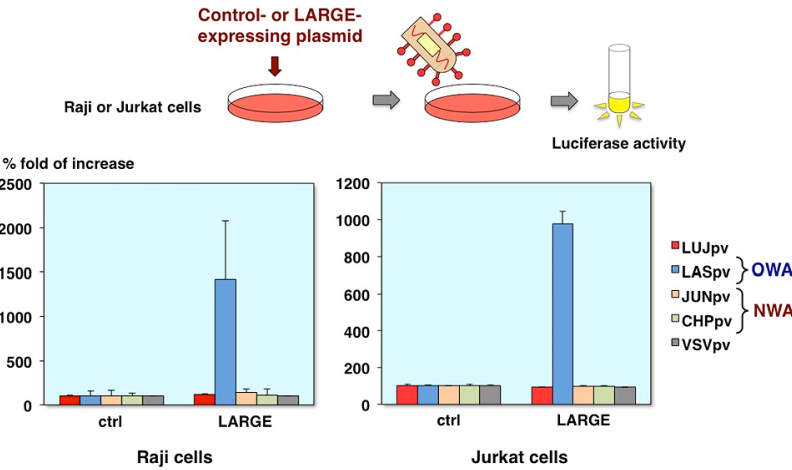

Fig. 11. Infectivities of AREpv in Raji or Jurkat cells expressing O-mannosylated $\alpha$-DG 
Furthermore, we confirmed involvement of DG by using the DG-knockout ES cells. The cells were transfected with control or DG expressing plasmid and infected with pseudotype viruses [9]. As you can see, only Lassa virus pseudotype infection was increased in DGexpressing cells. These results indicate that Lujo virus pseudotype infection is independent of both the DG and TfR1 (Fig. 13).

Many viral envelope proteins have a potential to change the conformation and cell fusion activities in low $\mathrm{pH}$ exposure. To examine cell fusion activities of arenavirus GPs, the GP expressing cells were treated with the

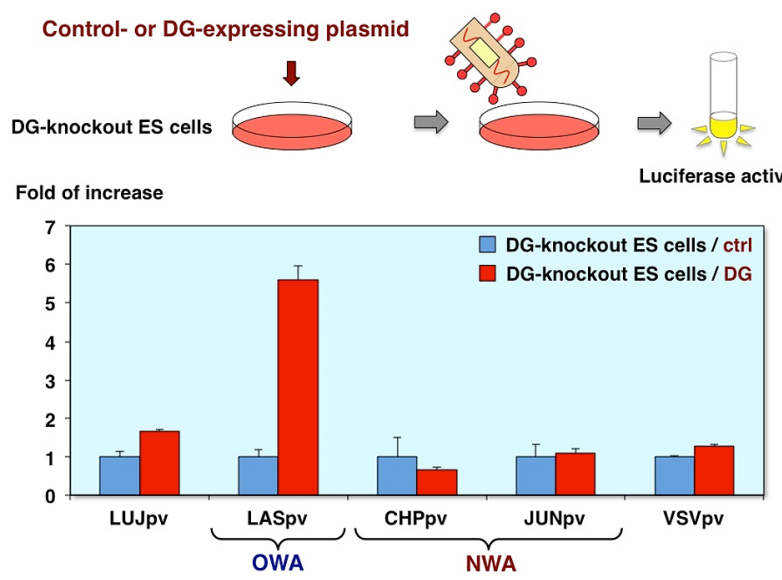

Fig. 12. Infectivities of AREpv in DG-knockout ES cells expressing $\alpha$-DG indicated $\mathrm{pH}$ buffers. As you can see, the syncytium formations were observed in Lassa, Junin, Chapare virus GP, and VSV-G expressing cells under low $\mathrm{pH}$ conditions. In contrast, surprisingly, no syncytium formation was observed in Lujo virus GP expressing cells even at pH4.0 buffer treatment (Fig. 14).

Similarly, by using two different plasmids encoding, the luciferase gene under the control of the $\mathrm{T} 7$ promoter and $\mathrm{T} 7$ polymerase, the cell fusion activities were evaluated by the luciferase reporter assay [10]. As you can see, the cell fusion activities were observed in Lassa, Junin, Chapare virus GP, and VSV-G expressing cells, but not Lujo virus GP expressing cells under low $\mathrm{pH}$ conditions (Fig. 15).

We also examined the effects of low $\mathrm{pH}$ exposure on arenavirus pseudotype infection. The viruses were treated with the indicated $\mathrm{pH}$ buffer before infection. After neutralization with the culture medium, the infectivities were evaluated.

As you can see, all of the arenavirus pseudotypes including the Lujo virus pseudotype infections were abolished after low $\mathrm{pH}$ buffer treatment. In contrast, VSV pseudotype can infect to the cells even at the low $\mathrm{pH}$ buffer treatment, because VSVG is reversible to change the $\mathrm{pH}$-triggered conformation. Together with the cell fusion experiments, the Lujo virus GP is changed conformation at low $\mathrm{pH}$, but some kind of molecules, which do not express at the plasma membrane, maybe needed for the membrane fusion (Fig. 16).

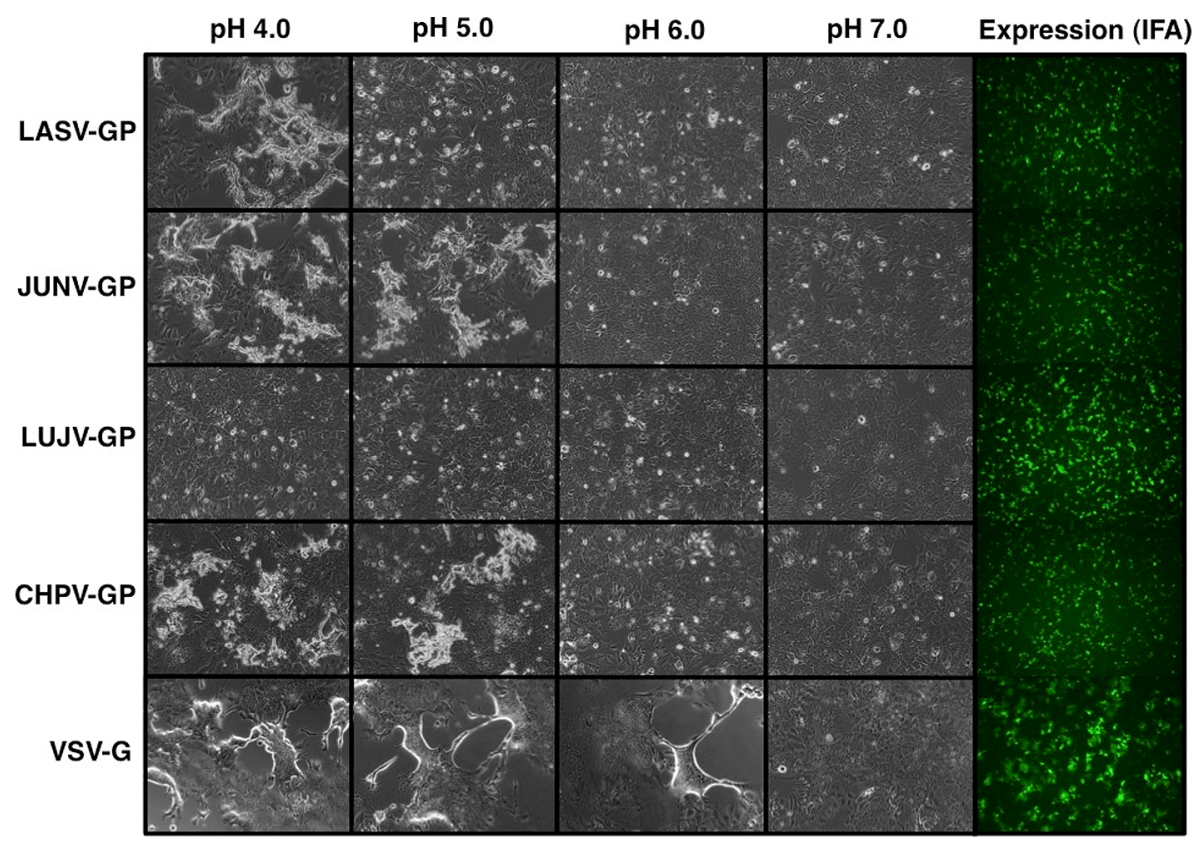

Fig. 13. Syncytium formation by arenavirus GP in $\mathrm{pH}$-dependent manner 

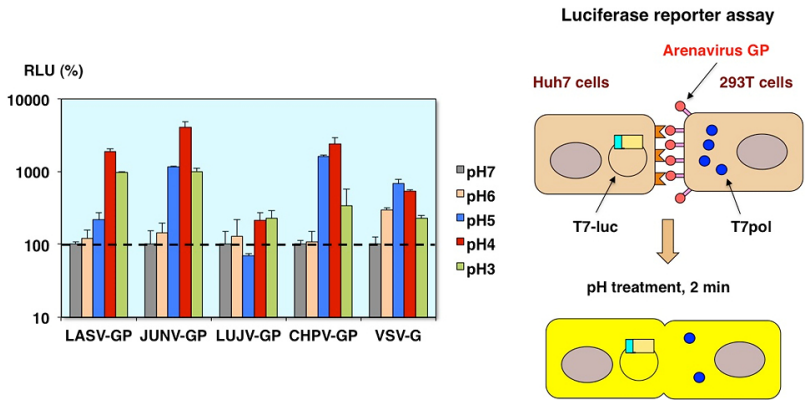

Fig. 14. Cell fusion reporter assay of arenavirus GP

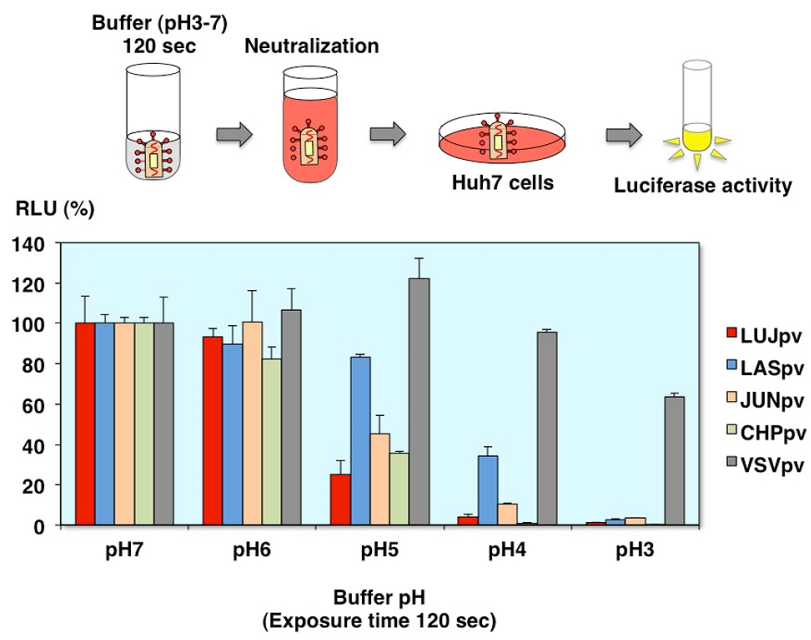

Fig. 15. Effects of low $\mathrm{pH}$ exposure on AREpv infection

To further examine the entry pathways of arenavirus pseudotype, we utilized chlorpromazine [7, 11]. This chemical is broadly known not only inhibitor for the clathrin-mediated endocytosis, but also inducer for lipidosis. As you can see, all of the arenavirus pseudotype infections were inhibited by the treatment with chlorpromazine in a dose dependent manner, especially the Lujo virus and Lassa virus pseudotype infections drastically reduced (Fig. 17).

Recently, it is reported that Ebola virus infection is involved in the cholesterol transporter protein, NiemannPick C1, NPC1, and acid sphingomyelinase, which is the hydrolase enzyme involved in the sphingolipid metabolism [12-14] (Fig. 18).

So, to examine the role of lipid metabolism in arenavirus infection, we utilized the other lipidosis-inducing drugs, imipramine, desipramine, amitriptyline. These drugs are known to the anti-depressant drugs, and cause lipid accumulation in vitro. As you can see, the Lujo virus pseudotype as well as the Ebola virus pseudotype infections were inhibited by these drugs (Fig. 19).

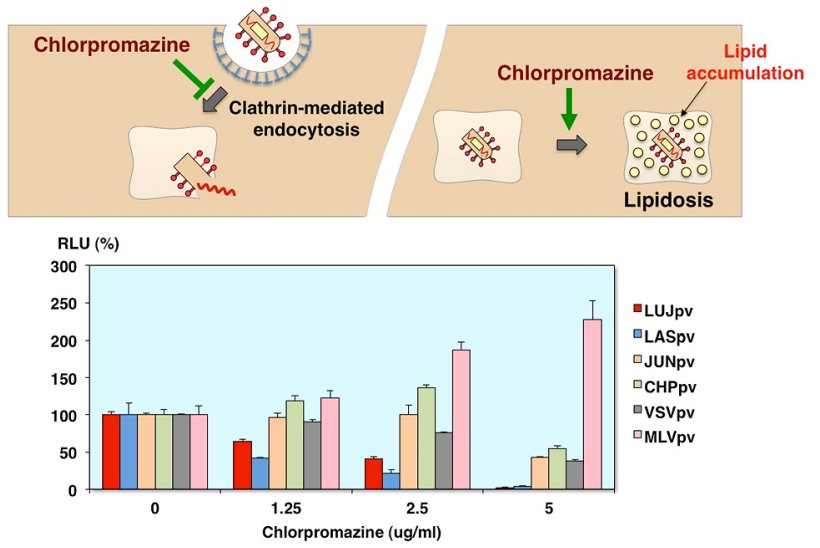

Fig. 16. Inhibition of AREpv infection by chlorpromazine

NPC1

$\checkmark$ Ebola virus entry requires the cholesterol transporter Niemann-Pick C1

J. E. Carette, et al., 2011, Nature

$\checkmark$ Ebola virus entry requires the host-programmed recognition of an intracellular receptor

E. H. Miller, et al., 2012, EMBO J

SMase

$\checkmark$ Ebolavirus requires acid sphingomyelinase activity and plasma membrane sphingomyelin for infection

M. E. Miller, et al., 2012, J Virol

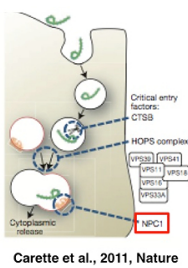

Fig. 17. Roles of lipid metabolism in Ebola virus infection

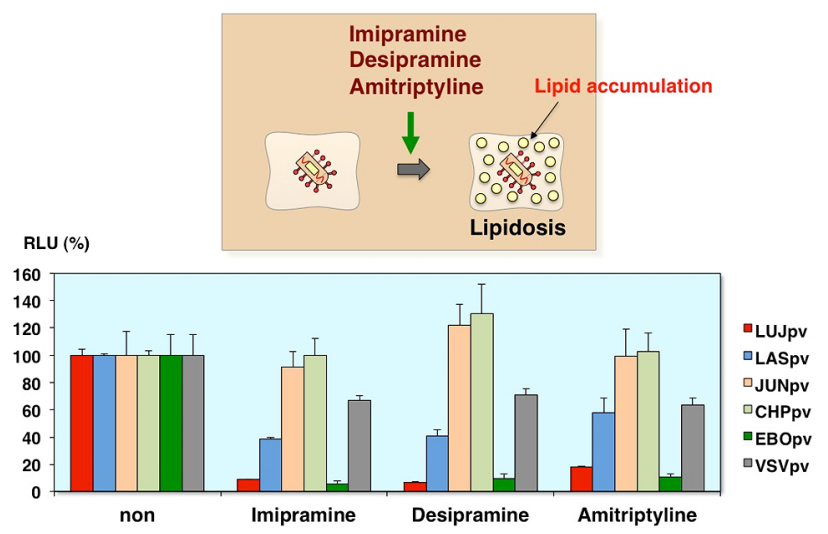

Fig. 18. Inhibition of AREpv infection by lipidosis-inducing drugs

Furthermore, we utilized the cholesterol transport inhibitor, U18666A, to examine the effects of arenavirus pseudotype infection. This inhibitor has a similar activity to inhibit the function of NPC1, so the Ebola virus entry was abolished. As you can see, the Lujo virus pseudotype infection as well as Ebola virus pseudotype infection was 
inhibited by this inhibitor in a dose-dependent manner. Now, we are investigating the involvement of NPC1 with Lujo virus pseudotype entry (Fig. 20).

This is the conclusion to the first part: The Lujo virus GP contains high-mannose type of glycosylation. The Lujo virus pseudotype is not susceptible to some cell lines. The entry is $\mathrm{pH}$ dependent. The Lujo virus GP does not have cell-to-cell fusion activities. The Lujo virus pseudotype utilizes neither $\alpha$-DG nor TfR1 as receptors. The lipidosis in endosomes inhibits Lujo virus pseudotype entry (Fig. 21).

In summary, the Lujo virus entered the target cells via

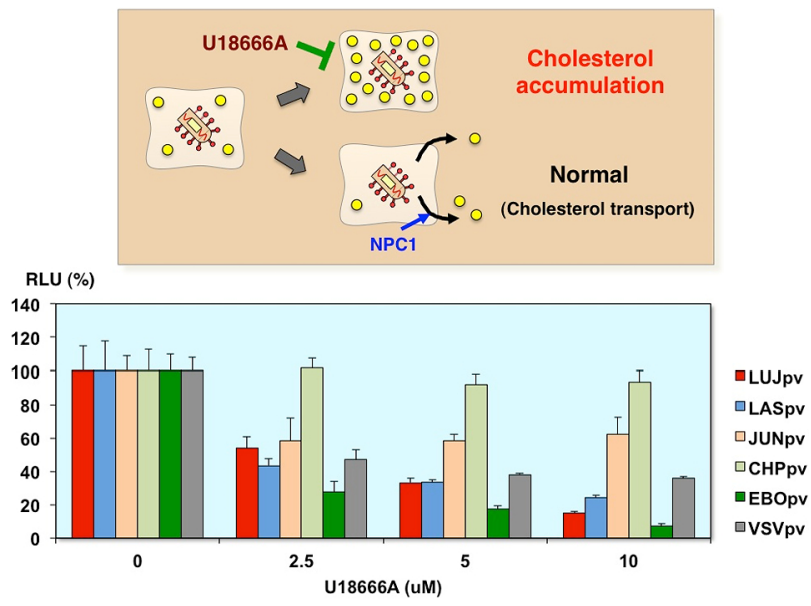

Fig. 19. Inhibition of AREpv infection by cholesterol transport inhibitor

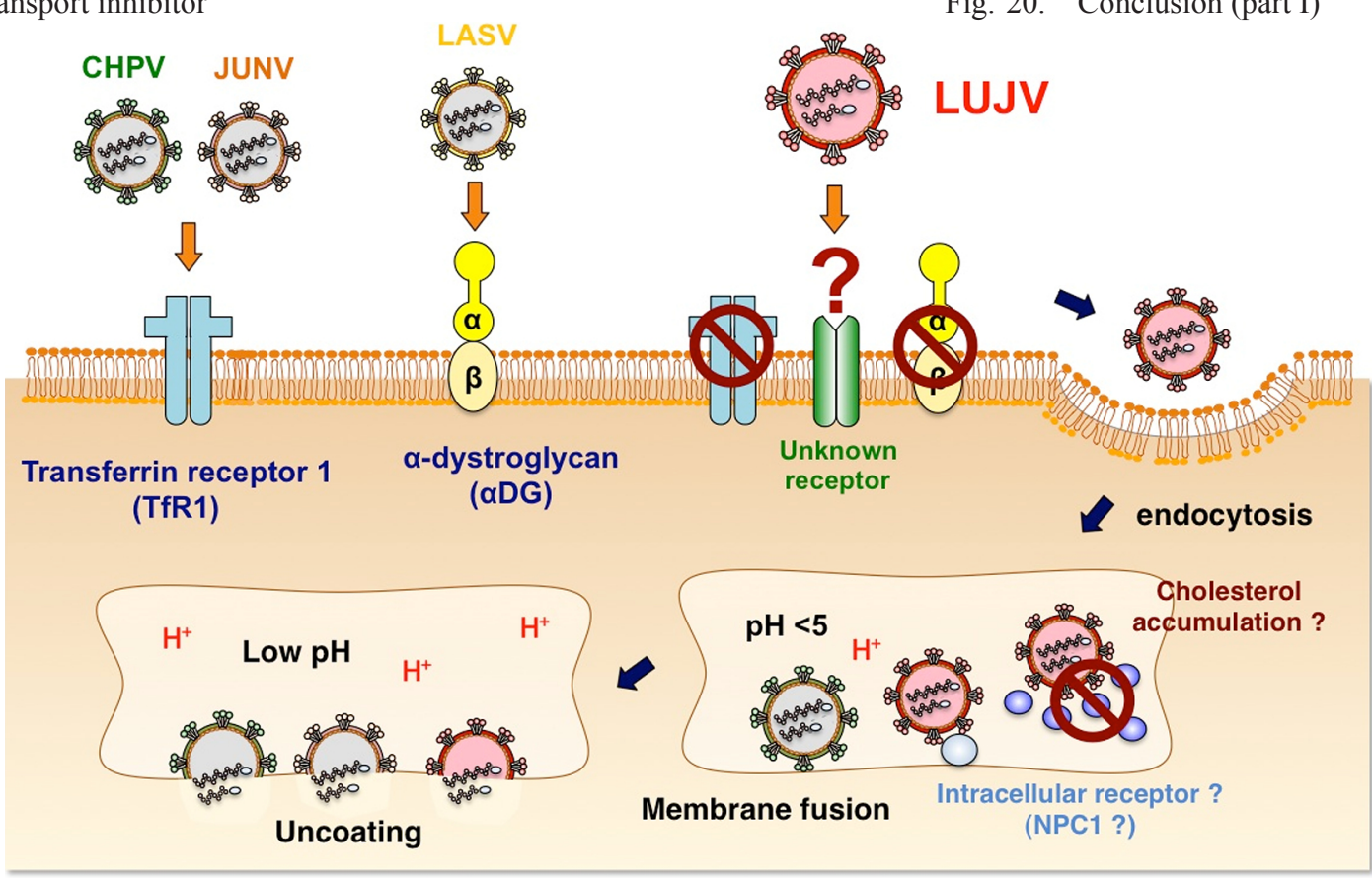

Fig. 21. Schematic model of arenavirus (Lujo virus) cell entry

unknown receptors but not TfR 1 and $\alpha$-DG. The viruses were endocytosed at low $\mathrm{pH}$, but some kind of intracellular receptor molecules such as NPC1 for Ebola virus may be needed in endosomal membrane fusion. And, this interaction may be needed to exclude the cholesterol or phospholipid accumulation. Lujo virus may have a unique entry mechanism and further precise studies will be needed (Fig. 22). Japan. This is the paper of the New England Journal of Medicine published in 2011 [15]. The SFTS emerged in 2009-2010 at six provinces in China. The novel Bunyavirus designated SFTSV, was isolated from the blood samples of SFTS patients (Fig. 23). patient was found in Yamaguchi Prefecture [16]. Until last

$\checkmark$ Lujo virus GP contains high-mannose-type glycosylation.

$\checkmark$ LUJpv is not susceptible to some mouse cell lines.

$\checkmark$ LUJpv entry is pH-dependent.

$\checkmark$ Lujo virus GP does not have cell-cell fusion activities.

$\checkmark$ LUJpv utilizes neither aDG nor TfR1 as receptors.

$\checkmark$ Lipidosis in endosomes inhibits LUJpv entry.

Fig. 20. Conclusion (part I)

Okay, second part of my presentation is SFTS in

In Japan, last autumn, the first diagnosed SFTS 

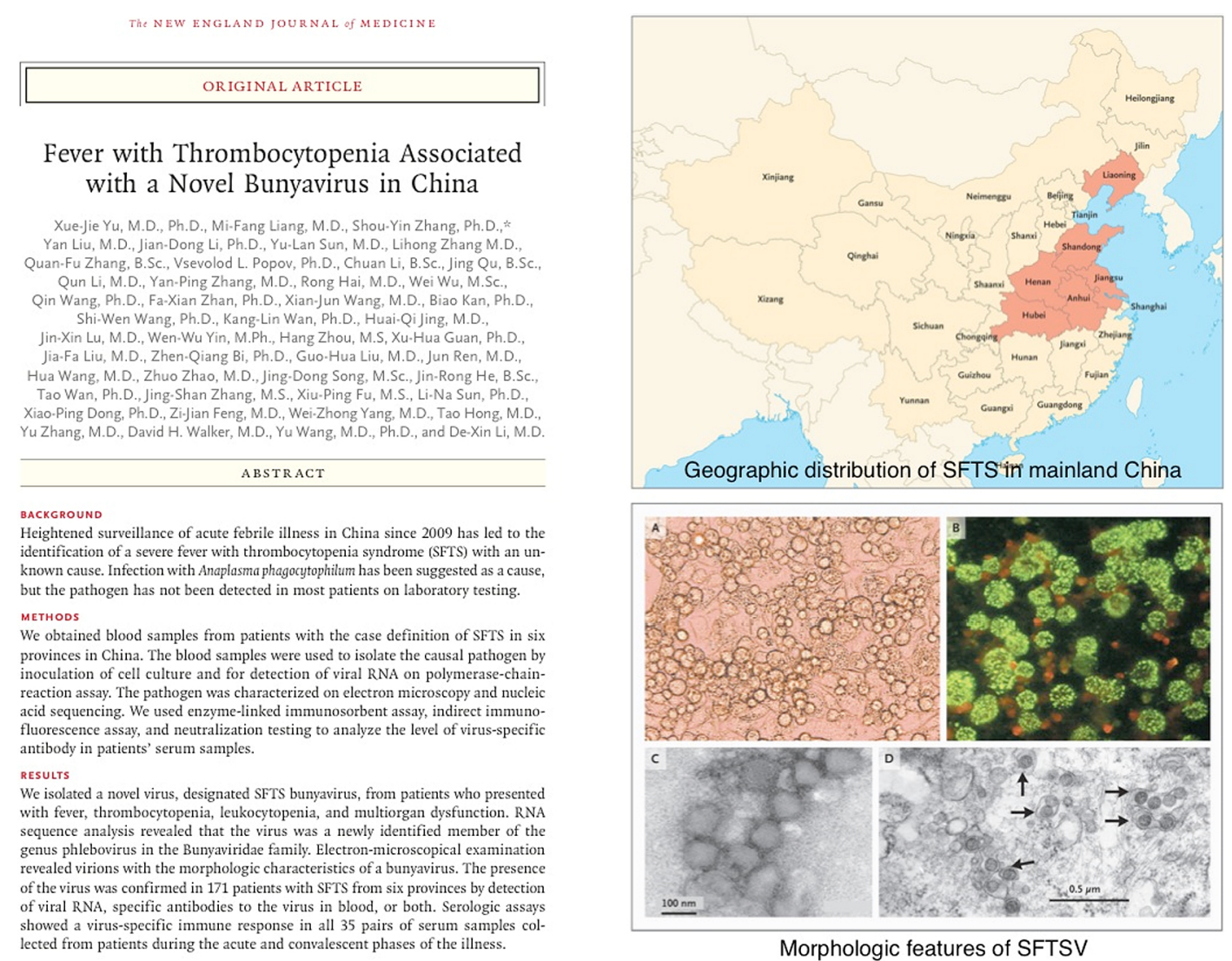

Fig. 22. Published paper of SFTS in China

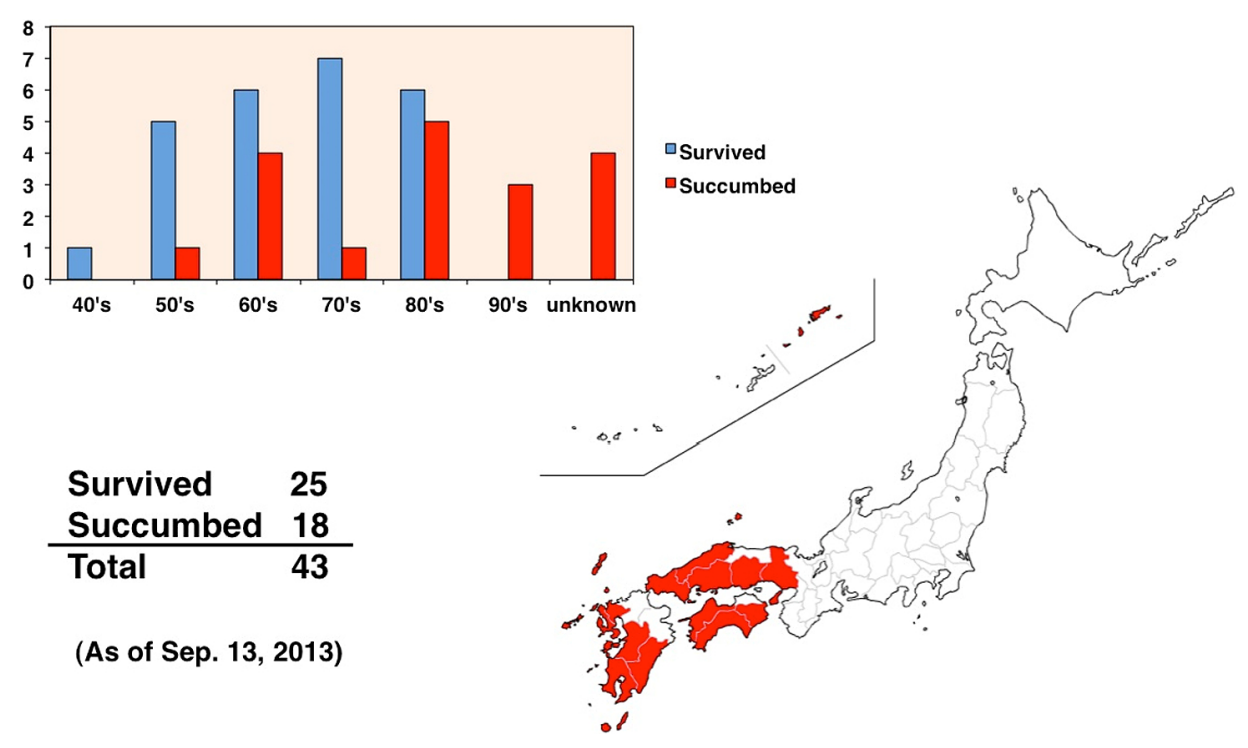

Fig. 23. Age and area incidence of SFTS in Japan

month, including the retrospective studies, total 43 people were infected with the SFTSV and 18 people died. Up to the present, we do not know the exact reason, but the SFTS occurs almost in western part of Japan including the Nagasaki Prefecture (Fig. 24).

This slide summarizes the characteristics of SFTSV. 
The SFTSV belongs to the Family Bunyaviridae and the Genus Phlebovirus. The Rift Valley fever virus is the same genus. This virus has three segmented negative-stranded RNA; L, M, and S shown here. This virus is visualized with a diameter of 80 to 100 nanometer as shown here and detected from the ixodid tick such as Haemaphysalis longicornis, the Japanese name is Futatogechimadani. The fatality rate is around $10 \%$ to $30 \%$. The major clinical symptoms of SFTS are fever and thrombocytopenia which means lower platelet count and leucopenia which means low white blood cell count. In the laboratory, the virus is easily isolated from Vero cells as shown here. But this virus is classified as a BSL-3 pathogen. So, to further operate easily, we tried to construct pseudotype virus possessing the SFTSV GP (Fig. 25).

At first, we examined the localization of SFTSV-GP in Vero cells infected with the SFTSV or transfected with the GP expressing plasmid. As you can see, both GPs did

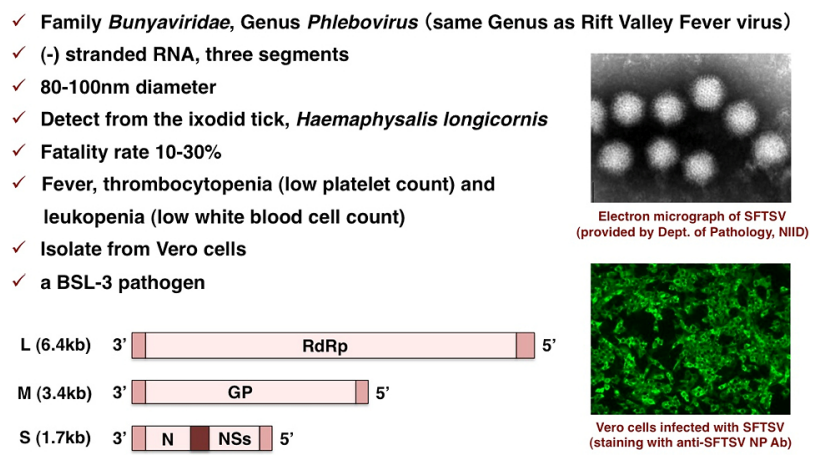

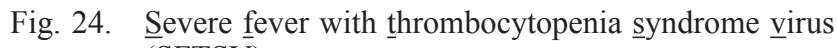
(SFTSV) not express at the plasma membrane but mainly localized in the ER or Golgi apparatus (Fig. 26).

Generally, VSV were budded from the plasma membrane, so the cell surface expressed GPs were efficiently incorporated into the virions, and these pseudotype viruses showed highly infectious [17]. In contrast, the cytosolic expressed GP such as the SFTSV-GP was not efficiently incorporated into the virions. But rarely a small portion of the VSV maybe budded from the ER or Golgi, and these VSVs incorporated the GP into the virions and showed moderately infectious (Fig. 27).

This slide shows the infectivities of SFTSV pseudotype in various mammalian cells. The Rift Valley fever virus and 100-diluted VSV pseudotypes were used as the control for the comparison. The SFTSV pseudotype virus can infect many types of cells, but are not susceptible to the lymphocyte cell lines (Fig. 28).

As shown in first part of my presentation, SFTSV pseudotype infection was also inhibited by the bafilomycin and ammonium chloride. That means this virus infection is required for the endosomal acidification (Fig. 29).

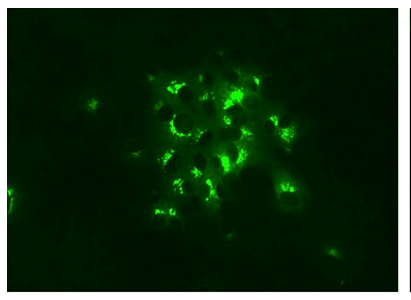

SFTSV infection

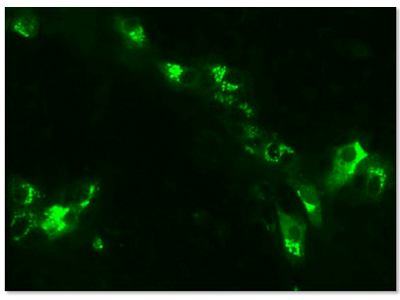

SFTSV-GP plasmid transfection
Fig. 25. Localization of SFTSV-GP in Vero cells

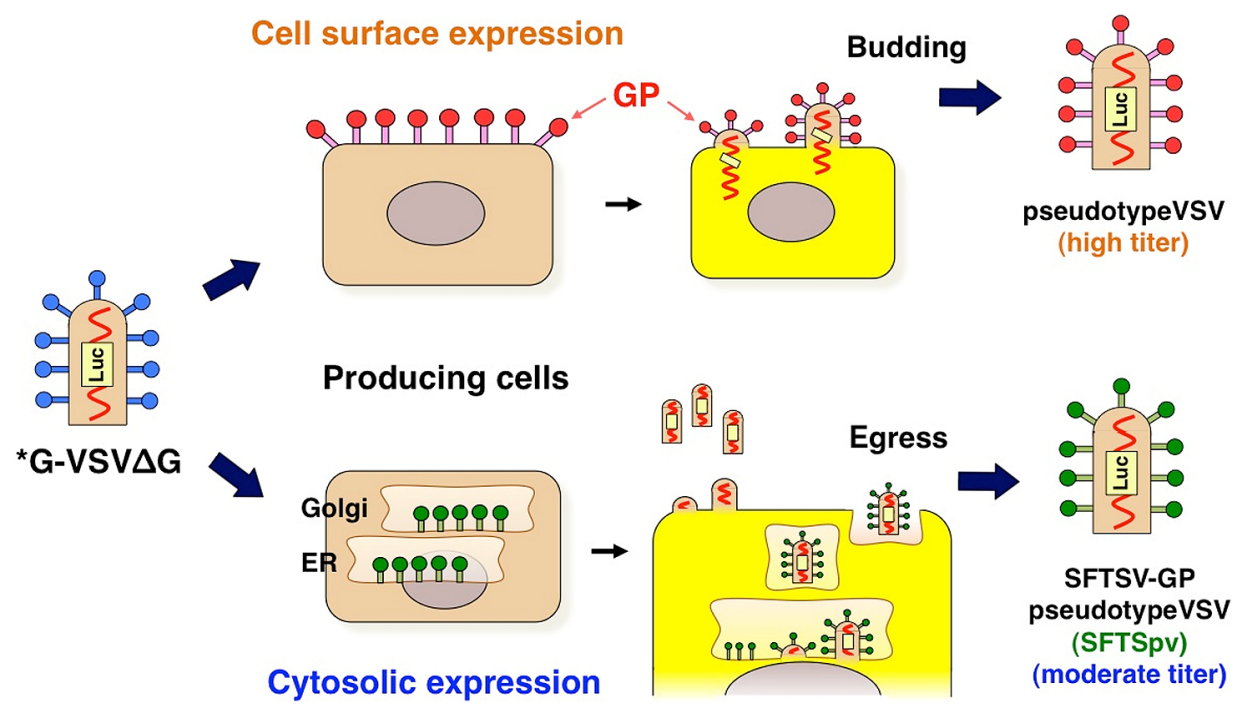

Fig. 26. Putative model of construction of SFTSVpv 


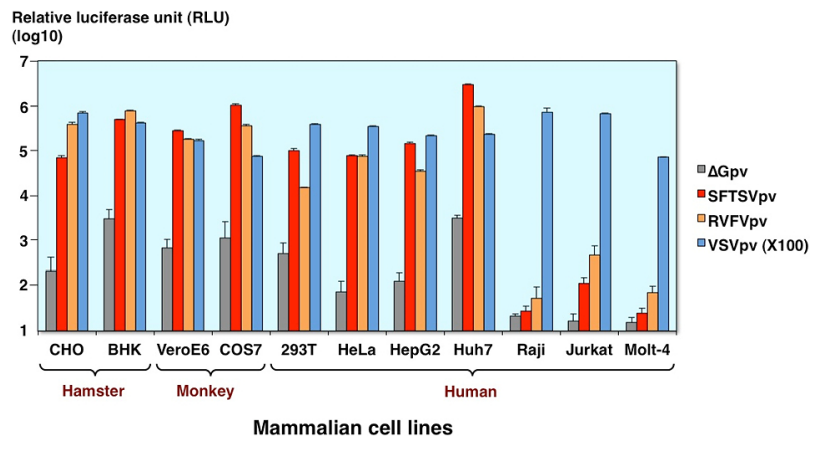

Fig. 27. Infectivities of SFTSVpv in various mammalian cells
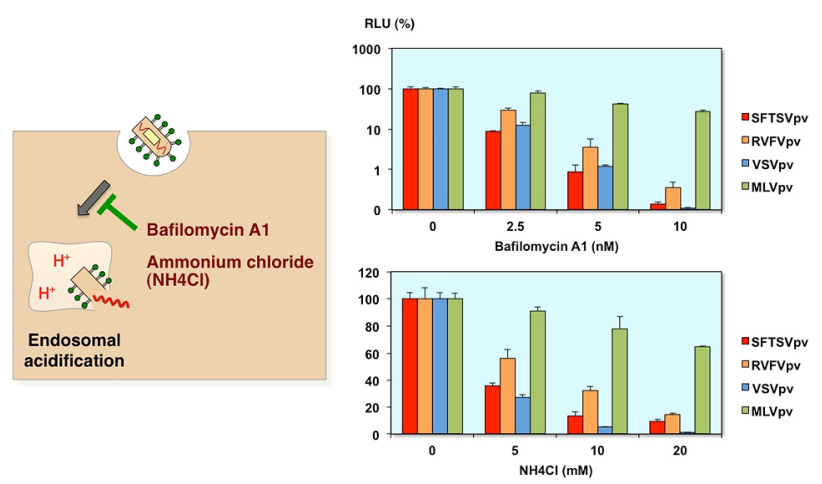

Fig. 28. Inhibition of SFTSVpv infection by $\mathrm{H}^{+}$-ATPase inhibitors
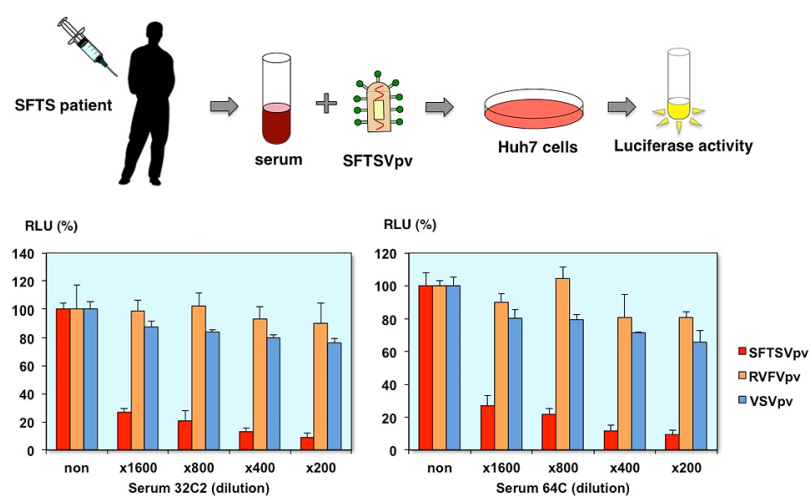

Fig. 29. Neutralization of SFTSVpv infection by patient sera

Finally, we examined neutralization tests using the pseudotype viruses. The SFTSV pseudotype is specifically neutralized by the serial dilution of patient serum. These results indicate that the neutralizing antibodies are present in the serum of convalescent patient and pseudotype virus is a useful tool for the neutralization test (Fig. 30).

This is the conclusion to the second part. The SFTS is endemic, especially to the western part of Japan. The pseu-

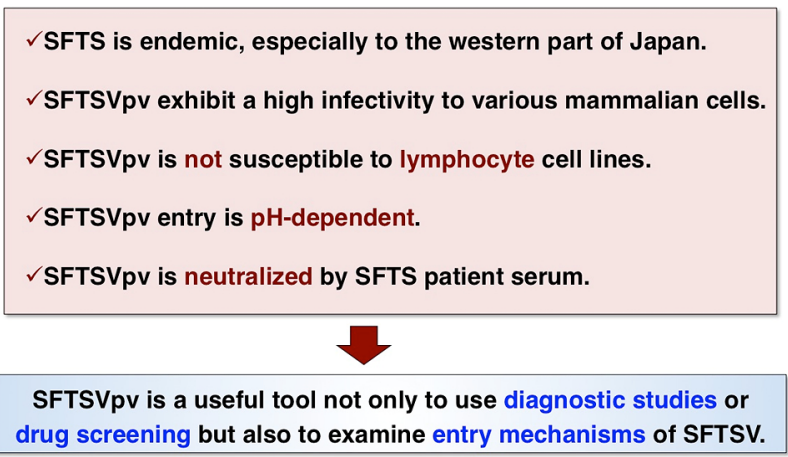

Fig. 30. Conclusion (part II)

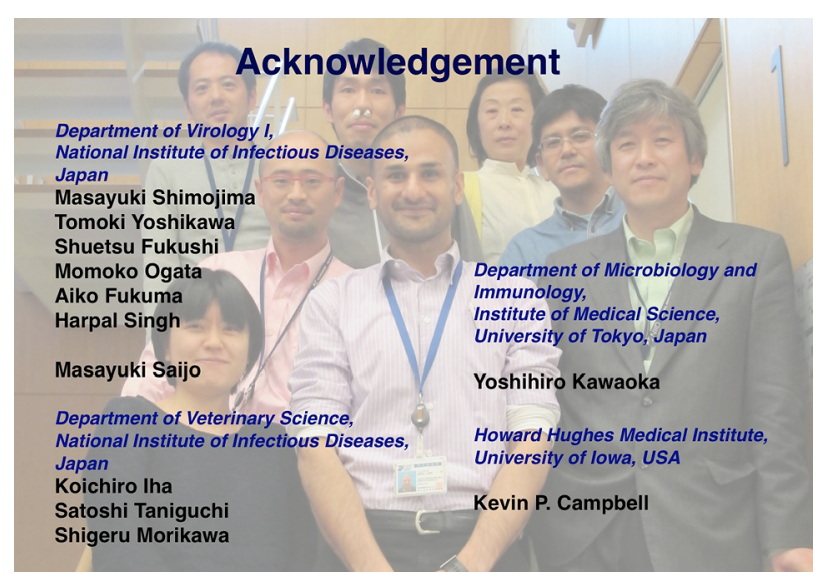

Fig. 31 Collaborator

dotype virus exhibits a high infectivity to various mammalian cells. The pseudotype is not susceptible to lymphocyte cell lines. The entry is $\mathrm{pH}$ dependent. The pseudotype virus is neutralized by SFTS patient serum, so the SFTSV pseudotype is a useful tool not only to use diagnostic studies or drug screening but also to examine entry mechanisms of SFTSV (Fig. 31.).

Finally, thanks to all the members of Department of Virology I and Department of Veterinary Science, National Institute of Infectious Diseases, and the DG knockout ES cells were kindly provided by Drs. Kawaoka and Campbell.

Thank you very much for your attention.

\section{Questions AND Discussion}

Male Participant Thank you for your nice presentation. About SFTS, SFTS-G is processed in the cells and do you confirm the GN and GC incorporated to the virus particle, both GN, GC is incorporated to the virus particle? 
Shigeru Morikawa Live virus.

Hideki Tani Pseudotype virus?

Male Participant Yes.

Hideki Tani We need to check the incorporation of the GP. But now we do not have appropriate antibodies for detecting the GP with western blotting. We also need to make them. Thank you.

Shigeru Morikawa Other questions? So I've got one question. While using the bafilomycin or some other treatment, the Lujo virus entry is associated with maybe NPC-1 or some other things. But at the same time, the Lassa virus pseudotype infection is also inhibited by the similar inhibitors. So, in this experiment, do you think the Lassa also utilized NPC or some other factors?

Hideki Tani Yeah, that's a good question. The Lassa virus pseudotype also partially inhibited this NPC-1 inhibitor. But we don't have the data to compare the Lassa virus GP and Lujo virus GP. We need to compare these GP in the future.

Jiro Yasuda Thank you very much for interesting talk. I have one comment and one question. First one is comment. Unfortunately, BSL-4 facility is not working in Japan at present, so we have to use these surrogate systems instead of infection system using authentic viruses, especially for highly virulent viruses. So, it's a critical program which we are facing now. So it's the comment.

Next one is question. My question is natural host of Lujo virus has not been identified, and in this presentation you showed mouse cells were not susceptible to Lujo GP pseudotyped VSV. So, does it mean mouse would be not natural host for Lujo virus because most of Old World RNA virus, natural hosts are rodent?

Hideki Tani That's a good question. Yeah, I think that maybe the mouse cell lines are different to the animal tissue or primary cells. Our data did not conclude not susceptible to the virus host and we need to check primary cells or animal experiments.

Shigeru Morikawa I have one question on the SFTS. Because in human patient, the main target of the cells in vivo is maybe lymphocyte, because in the lymph node, there are many cells infected, but not in the other epithelial cells like hepatocytes or some others. But in vitro basing this system or basing the SFTS virus itself, the virus can infect a variety of cells, but except for the lymphocyte. What do you think about this discrepancy?

Hideki Tani Yeah, that's the same situation of Lujo virus infection. Raji cells are not susceptible to the SFTSV infection in our studies as well as reported in the previous studies, but DC or some macrophages cells infected with SFTSV, so that maybe different to the cell line and the primary cells. We need to study about it.

Shigeru Morikawa Okay, anyway, maybe I think you can find a receptor for SFTS using this system. Thank you very much, Dr. Tani.

\section{REFERENCES}

1. Charrel RN, de Lamballerie X. Zoonotic aspects of arenavirus infections. Vet Microbiol 2010; 140: 213-220.

2. Buchmeier MJ, Peters CJ, de la Torre JC. Arenaviridae: The Virus and their Replication. Fields Virology. 5th ed. Vol. 2. Philadelphia: Lippincott Williams \& Wilkins; 2007. pp 1792-1827.

3. Briese T, Paweska JT, McMullan LK, Hutchison SK, Street C, Palacios G, Khristova ML, Weyer J, Swanepoel R, Egholm M, Nichol ST, Ian Lipkin W. Genetic detection and characterization of Lujo virus, a new hemorrhagic fever-associated arenavirus from South Africa. PLoS Pathog 2009; 5: e1000455.

4. Fukushi S, Tani H, Yoshikawa T, Saijo M, Morikawa S. Serological assays based on recombinant viral proteins for the diagnosis of arenavirus hemorrhagic fevers. Viruses 2012; 4: 2097-2114.

5. Tani H, Morikawa S, Matsuura Y. Development and applications of VSV vectors based on cell tropism. Front Microbiol 2012; 2: 272.

6. Rojek JM, Spiropoulou CF, Campbell KP, Kunz S. Old World and clade $\mathrm{C}$ New World arenaviruses mimic the molecular mechanism of receptor recognition used by adystroglycan's host-derived ligands. J Virol 2007; 81: 5685-5695.

7. Tani H, Shiokawa M, Kaname Y, Kambara H, Mori Y, Abe T, Moriishi K, Matsuura Y. Involvement of ceramide in the propagation of Japanese encephalitis virus. J Virol 2010; 84: 2798-2807.

8. Kunz S, Rojek JM, Kanagawa M, Spiropoulou CF, Barresi R, Campbell KP, Oldstone MB. Posttranslational modification of alpha-dystroglycan, the cellular receptor for arenaviruses, by the glycosyltransferase LARGE is critical for virus binding. J Virol 2005; 79: 14282-14296.

9. Shimojima M, Ströher U, Ebihara H, Feldmann H, Kawaoka Y. Identification of cell surface molecules involved in dystroglycan-independent Lassa virus cell entry. J Virol 2012; 86: 2067-2078.

10. Takikawa S, Ishii K, Aizaki H, Suzuki T, Asakura H, Matsuura Y, Miyamura T. Cell fusion activity of hepatitis C virus envelope proteins. J Virol 2000; 74: 5066-5074.

11. Kataoka C, Kaname Y, Taguwa S, Abe T, Fukuhara T, Tani H, Moriishi K, Matsuura Y. Baculovirus GP64mediated entry into mammalian cells. J Virol 2012; 86: 2610-2620.

12. Carette JE, Raaben $\mathrm{M}$, Wong AC, Herbert AS, 
Obernosterer G, Mulherkar N, Kuehne AI, Kranzusch PJ, Griffin AM, Ruthel G, Dal Cin P, Dye JM, Whelan SP, Chandran K, Brummelkamp TR. Ebola virus entry requires the cholesterol transporter Niemann-Pick $\mathrm{C} 1$. Nature 2011; 477: 340-343.

13. Miller EH, Obernosterer G, Raaben M, Herbert AS, Deffieu MS, Krishnan A, Ndungo E, Sandesara RG, Carette JE, Kuehne AI, Ruthel G, Pfeffer SR, Dye JM, Whelan SP, Brummelkamp TR, Chandran K. Ebola virus entry requires the host-programmed recognition of an intracellular receptor. EMBO J 2012; 31: 1947-1960.

14. Miller ME, Adhikary S, Kolokoltsov AA, Davey RA. Ebolavirus requires acid sphingomyelinase activity and plasma membrane sphingomyelin for infection. J Virol 2012; 86: 7473-7483.

15. Yu XJ, Liang MF, Zhang SY, Liu Y, Li JD, Sun YL, Zhang L, Zhang QF, Popov VL, Li C, Qu J, Li Q, Zhang YP, Hai R, Wu W, Wang Q, Zhan FX, Wang XJ, Kan B, Wang SW, Wan KL, Jing HQ, Lu JX, Yin WW, Zhou H, Guan XH, Liu JF, Bi ZQ, Liu GH, Ren J, Wang H, Zhao Z, Song JD, He JR, Wan T, Zhang JS, Fu XP, Sun LN, Dong XP, Feng ZJ, Yang WZ, Hong T, Zhang Y, Walker DH, Wang Y, Li DX. Fever with thrombocytopenia asso- ciated with a novel bunyavirus in China. N Engl J Med 2011; 364: 1523-1532.

16. Takahashi T, Maeda K, Suzuki T, Ishido A, Shigeoka T, Tominaga T, Kamei T, Honda M, Ninomiya D, Sakai T, Senba T, Kaneyuki S, Sakaguchi S, Satoh A, Hosokawa T, Kawabe Y, Kurihara S, Izumikawa K, Kohno S, Azuma T, Suemori K, Yasukawa M, Mizutani T, Omatsu T, Katayama Y, Miyahara M, Ijuin M, Doi K, Okuda M, Umeki K, Saito T, Fukushima K, Nakajima K, Yoshikawa T, Tani H, Fukushi S, Fukuma A, Ogata M, Shimojima M, Nakajima N, Nagata N, Katano H, Fukumoto H, Sato Y, Hasegawa H, Yamagishi T, Oishi K, Kurane I, Morikawa S, Saijo M. The First Identification and Retrospective Study of Severe Fever with Thrombocytopenia Syndrome in Japan. J Infect Dis 2014; 209(6): 816-827. doi: $10.1093 /$

17. Tani H, Komoda Y, Matsuo E, Suzuki K, Hamamoto I, Yamashita T, Moriishi K, Fujiyama K, Kanto T, Hayashi N, Owsianka A, Patel AH, Whitt MA, Matsuura Y. Replication-competent recombinant vesicular stomatitis virus encoding hepatitis $\mathrm{C}$ virus envelope proteins. J Virol 2007; 81: 8601-8612. 